\title{
Log based petrophysical analysis of mio-pliocene sandstone reservoir encountered in well Rashidpur 4 of Bengal Basin in Bangladesh
}

\author{
M. Farhaduzzaman ${ }^{1 *}$, M. A. Islam ${ }^{2}$, W. H. Abdullah ${ }^{3}$ and J. Dutta ${ }^{4}$ \\ 1,3 Department of Geology, Faculty of Science, University of Malaya, 50603 Kuala Lumpur, Malaysia \\ ${ }^{2}$ Universiti Brunei Darussalam, Faculty of Science, Department of Petroleum Geoscience, Gadong BE1410, Brunei \\ ${ }^{4}$ Petroleum Geoscience Program, Chulalongkorn University, Bangkok, Thailand
}

\begin{abstract}
Rashidpur is located in the northeastern part of Bangladesh which is surrounded on three sides by India and on a small portion by Myanmar. Gamma-ray, spontaneous potential, density, neutron, resistivity, caliper, temperature and sonic logs are used to analyze petrophysical parameters of the well Rashidpur 4, Bangladesh. Quantitative measurements of different factors such as shale volume, porosity, permeability, water saturation, hydrocarbon saturation and bulk volume of water are carried out using well logs. Petrographic and XRD results based on several core samples are also compared with log-derived parameters. Twenty permeable zones are identified whereby four are hydrocarbon bearing in the studied Mio-Pliocene reservoir sandstones. Measured shale volume ranges from $11 \%$ to $38 \%$ and porosity is $19 \%$ to $28 \%$. However, log-derived porosity is slightly higher than the thin section porosity. Water saturation of the interested zones varies from $14 \%$ to $38 \%, 13 \%$ to $39 \%$ and $16 \%$ to $41 \%$ measured from Schlumberger, Fertl and Simandoux formula respectively. Conversely, hydrocarbon saturation of the examined hydrocarbon zones ranges from $62 \%$ to $86 \%, 61 \%$ to $83 \%$ and $59 \%$ to $84 \%$ respectively. In the analyzed zones, the permeability values are calculated as $28-305 \mathrm{mD}$. Good to very good quality hydrocarbon reservoirs are appraised for the studied four zones based on the petrophysical parameters, petrographic observation and XRD analysis. Among these, Zone 4 is the best quality reservoir for hydrocarbon.
\end{abstract}

Keywords: Petrophysics; Saturation; Porosity; Reservoir; Rashidpur 4

\section{Introduction}

Bangladesh lies in the northeastern corner of Indian subcontinent at the head of the Bay of Bengal (Fig.1). The Bengal Basin occupies entire Bangladesh (two-third of the basin) and part of surrounding India and Myanmar (Banerji 1984; Alam et al., 2003; Farhaduzzaman et al., 2013a and 2013b). During Eocene, the Bengal Basin evolved from the collision between northward drifting Indian plate and relatively passive Asian plate (Alam et al., 2003; Uddin and Lundberg, 2004). The generalized stratigraphy of the well RP4 can be shown in Table I. Estimated initial gas reserve in Bangladesh is 26.84 TCF with 42 TCF undiscovered (Jamaluddin et al., 2001; Shamsuddin et al., 2004; Imam, 2013). Crude oil production took place here from 1987 to 1997. Currently, out of 25 gas fields (including one minor oil filed) so far discovered, only 20 are producing. The gas production started in 1959. Now the daily production of gas and condensate is approximately 2736 MMCFD (million cubic feet per day) and 12377 BBLD (barrels per day) respectively (as of 04 Dec 2015; Petrobangla, 2015). The majority of gasfields in
Bangladesh produce dry gas while some producing a significant proportion of condensate.

Petrophysical log interpretation is one of the most useful and important tools to characterize the reservoir property (Asquith and Gibson, 1982). Well log data helps to identify permeable zones and productive zones for hydrocarbon. It distinguishes the interfaces of oil, gas or water of a particular reservoir. Permeable zones may contain either hydrocarbon or water or both. Petrophysical study involves the analysis of different parameters of reservoirs including lithology, volume of shale, porosity, water saturation, hydrocarbon saturation, permeability, hydrocarbon moveability and pore geometry by using appropriate well log data.

It provides the unique opportunity to observe the relationship between porosity and saturation (Sakurai et al., 2002). Reliable evaluation of hydrocarbon resources in shaly clastic reservoir rocks is an important task. The determination of reservoir quality and formation evaluation processes largely

\footnotetext{
*Corresponding author. e-mail: farhad.geo@siswa.um.edu.my; farhadgeo@gmail.com
} 


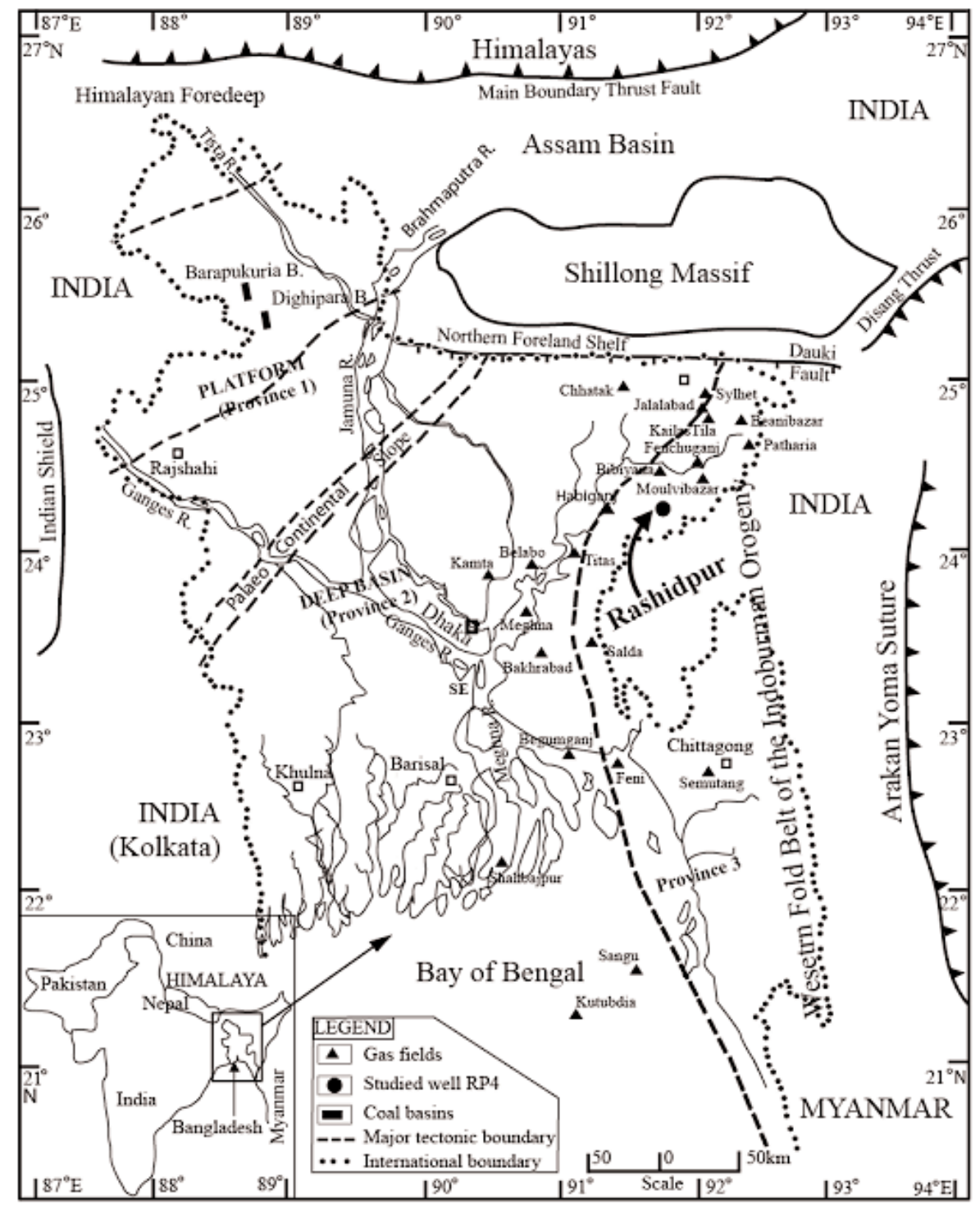

Fig. 1. Location map of the study area showing the major tectonic elements of the Bengal Basin, Bangladesh (modified after Farhaduzzaman et al., 2012a, 2012b and 2014).

depends on quantitative evaluation of petrophysical properties. In Bangladesh, the petrophysical evaluation of shaly sandstone has been performed in limited extent, for example, Islam et al. (2006 and 2009) and Islam (2010). Further studies are required with respect to petrophysical properties of the Bengal Basin. In the present study, attempts are made to analyze the petrophysical properties of shaly sand gas reservoir encountered in the well Rashidpur 4 (RP4), the Bengal Basin, Bangladesh. The study also evaluates the reservoir potential of the Mio-Pliocene sandstones in the studied well.

\section{Materials and methods}

The scanned images (TIFF format) of gamma (GR), resistivity (deep and shallow), sonic, SP, neutron, density, temperature and caliper logs of the well Rashidpur 4 (RP4) were collected from BAPEX, Petrobangla for the present study. These TIFF images have been converted to digital data (LAS format) using Didger ${ }^{\circledR} 4$ software. Subsequently, the digitized LAS files have been transferred to Excel software which is used for current analysis. It covers a total gross thickness of $1463 \mathrm{~m}$ (depth 1310 - $2774 \mathrm{~m}$ ) of the well RP4. Nonetheless, for the purpose of thin section porosity analysis, Leica DMLP optical microscope was also used. 
Farhaduzzaman, Islam, Abdullah and Dutta

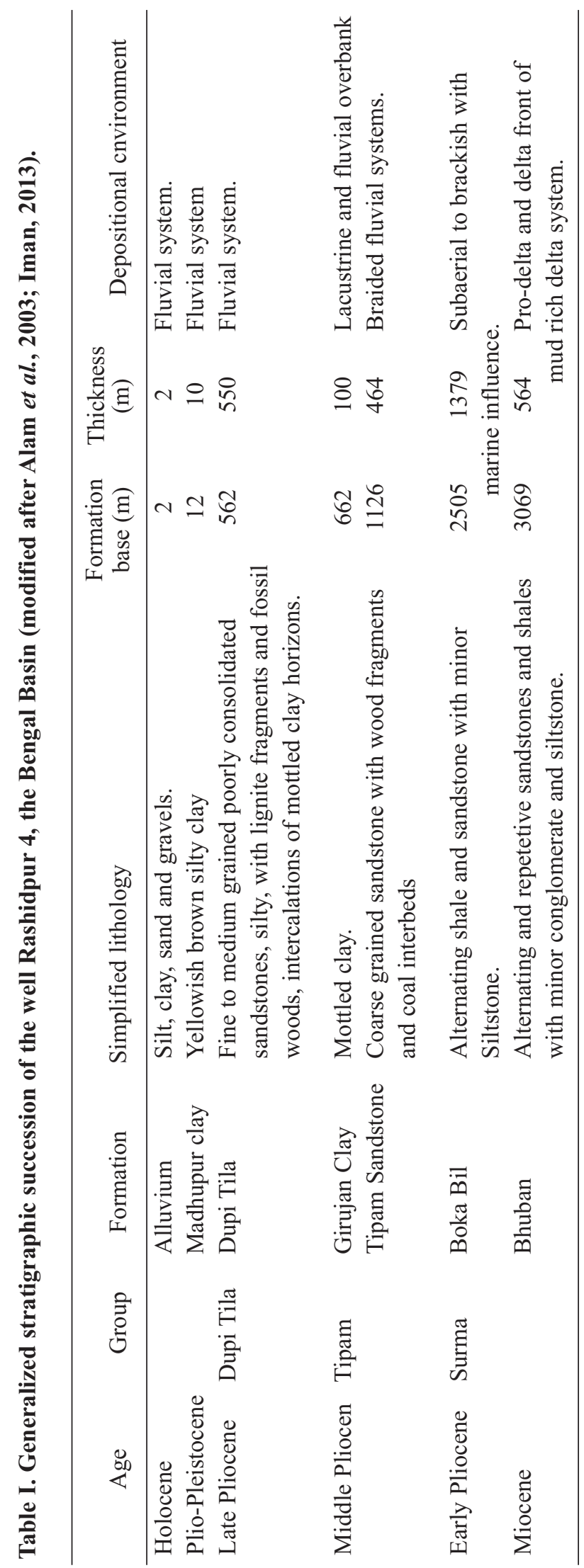

Shale volume

Calculating gamma ray index $\left(I_{G R}\right)$ is the first step needed to determine the volume of shale $\left(V_{S h}\right)$ from a gamma ray log (Atlas, 1979).

$\mathrm{I}_{G R}=\frac{G R_{\log }-G R_{\min }}{G R_{\max }-G R_{\min }}$

For Tertiary rocks, the shale volume can be measured from below:

$$
V_{s h}=0.083\left[2^{\left(3.7 \times I_{G R}\right)}-1.0\right]
$$

\section{Porosity}

Atlas (1979) proposed the following equation to calculate porosity from density log:

$\phi_{D e n}=\left(\frac{\rho_{m a}-\rho_{b}}{\rho_{m a}-\rho_{f}}\right)-V_{s h}\left(\frac{\rho_{m a}-\rho_{s h}}{\rho_{m a}-\rho_{f}}\right)$

The combined neutron and density log is used for getting the corrected porosity values (Schlumberger, 1975):

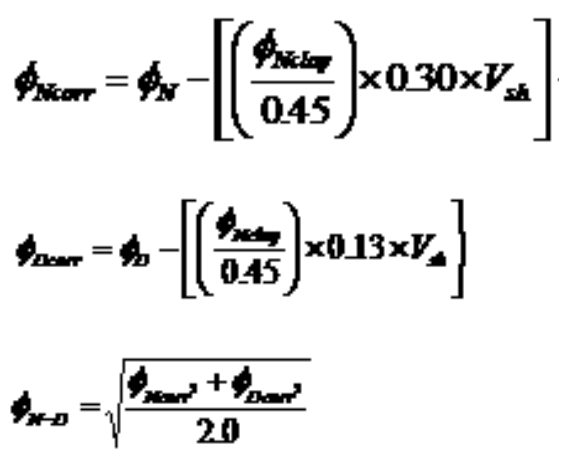

Thickness weighted average porosity (Bradley, 1987) is also measured as below:

$\phi_{a v}=\frac{\sum_{i=1}^{n} \phi_{t} h_{t}}{\sum_{i=1}^{n} h_{t}}$

\section{Water saturation}

Three more commonly used shaly-sand formulas for calculating water saturation $\left(S_{w}\right)$ can be shown as:

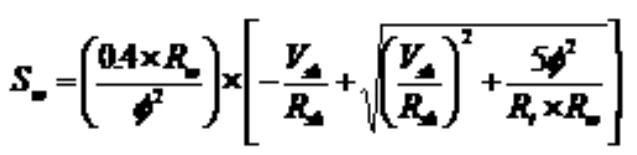




$$
\begin{aligned}
& S_{=}=\frac{1}{\phi} \times\left[\sqrt{\frac{R_{m}}{R_{f}}+\left(\frac{a \times V_{*}}{2}\right)^{2}}-\frac{a \times V_{-}}{2}\right] \\
& S_{-}=\frac{-\frac{V_{-}}{R_{+}}+\frac{\phi^{2}}{0.2 \times R_{-} \times\left(1.0-V_{+}\right) \times R_{1}}}{\frac{\phi^{2}}{0.4 \times R_{-} \times\left(1.0-V_{-}\right)}}
\end{aligned}
$$

Equation (8), (9) and (10) were introduced by Simandoux (1963) Fertl (1975) and Schlumberger (1975) respectively. Thickness weighted average water saturation is calculated using the following formula given by Bradley (1987).

$S_{\text {wav }}=\frac{\sum_{i=l}^{n} S w_{i} \phi_{i} h_{i}}{\sum_{i=l}^{n} \phi_{i} h_{i}}$.

Formation water resistivity

Formation water resistivity $\left(R_{w}\right)$ of the hydrocarbon bearing zone has been calculated from the formula given by Bateman and Konen (1977).

$$
\left.R=10^{\left\{\frac{x}{x}+4-\infty\right.}\right\}
$$

\section{Permeability}

The formula by Coates and Dumanoir (1973) is used for permeability (K).

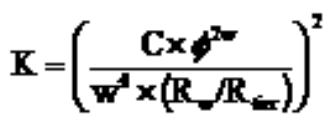

What, $W=\left[(3.75-\phi)+\left\{\frac{\left[\log \left\{R_{-}\right\}+22\right]^{F}}{2}\right\}\right]^{\frac{1}{2}}$

\section{ai $C=23+46 p_{n}-18 p^{2}$}

Permeability has also been calculated using Wyllie and Rose's (1950) formula:

$$
\mathrm{K}=\left(79 \times \phi^{3} / \mathrm{S}_{\text {wirr }}\right)^{2}(\text { dry gas })
$$

Thickness weighted average permeability is measured as stated below (Bradely, 1987).

$$
K_{a v}=\frac{\sum_{i=1}^{n} k_{i} h_{t}}{\sum_{i=1}^{n} h_{i}} .
$$

Hydrocarbon moveability

Movability of hydrocarbon is measured as follows:

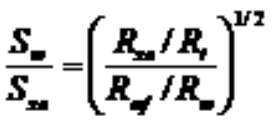

\section{Bulk volume of water}

The bulk volume of water (BVW) has been calculated using Morris and Biggs (1967) formula:

$$
B V W=S_{\mathbf{m}} \times
$$

\section{Results and discussion}

Identification of hydrocarbon bearing zones

Hydrocarbon bearing zones can be identified with the combined use of GR, SP, resistivity (RILD and RSFL), neutron, density and sonic log responses. Firstly, for gas exists, density response (RHOB) increases while the neutron porosity (NPHI) decreases. This is so called neutron-density 'crossover' or 'excavation effect' albeit it is not possible to show here since the two logs are shown in two different tracks. Secondly, for gas zone, shallow resistivity logs (MSFL) show low resistivity invasion profile. At the same time deep induction resistivity log (RILD) response is higher than the shallower resistivity. The deep induction resistivity is at least two times higher than that of the water zones with similar lithology and porosity (Asquith and Gibson, 1982) (Fig.2). Furthermore, gamma ray log shows low response compared to that of above or below section and deflection from the shale base line of SP log occurs in hydrocarbon bearing zones (Fig.2). However, sonic $\Delta \mathrm{T}$ response appears 'cycle skip' with slight increase in gas zones. In all of the identified 4 hydrocarbon bearing zones, some shales are interbedded with the reservoir sandstone which affects slightly the reservoir properties. In this study, 20 permeable zones have been identified from the composite $\log$ analysis of cumulative $1464 \mathrm{~m}$ thickness (1310-2774 m) of the well RP4. Among 
these permeable zones, four zones (cumulative thickness 168 $\mathrm{m})$ have been identified as hydrocarbon bearing while the remaing one water bearing. Some important log parameters and their average values of these 4 zones are shown in Table II and Table III. bon bearing zones of the well RP4 is $20 \%$ (Table III). Zone 3 contains the lowest and Zone 1 contains the highest volume of shale. Waxman and Smits (1968) suggested that CEC value $>0.2$ indicate smectite or illite type of clay, whereas CEC value $<0.2$ indicates kaolinite or chlorite. In the present study, CEC values are found to be $\sim 0.2$ which indicates mixed types of clay (i.e., chlorite, illite and kaolinite)

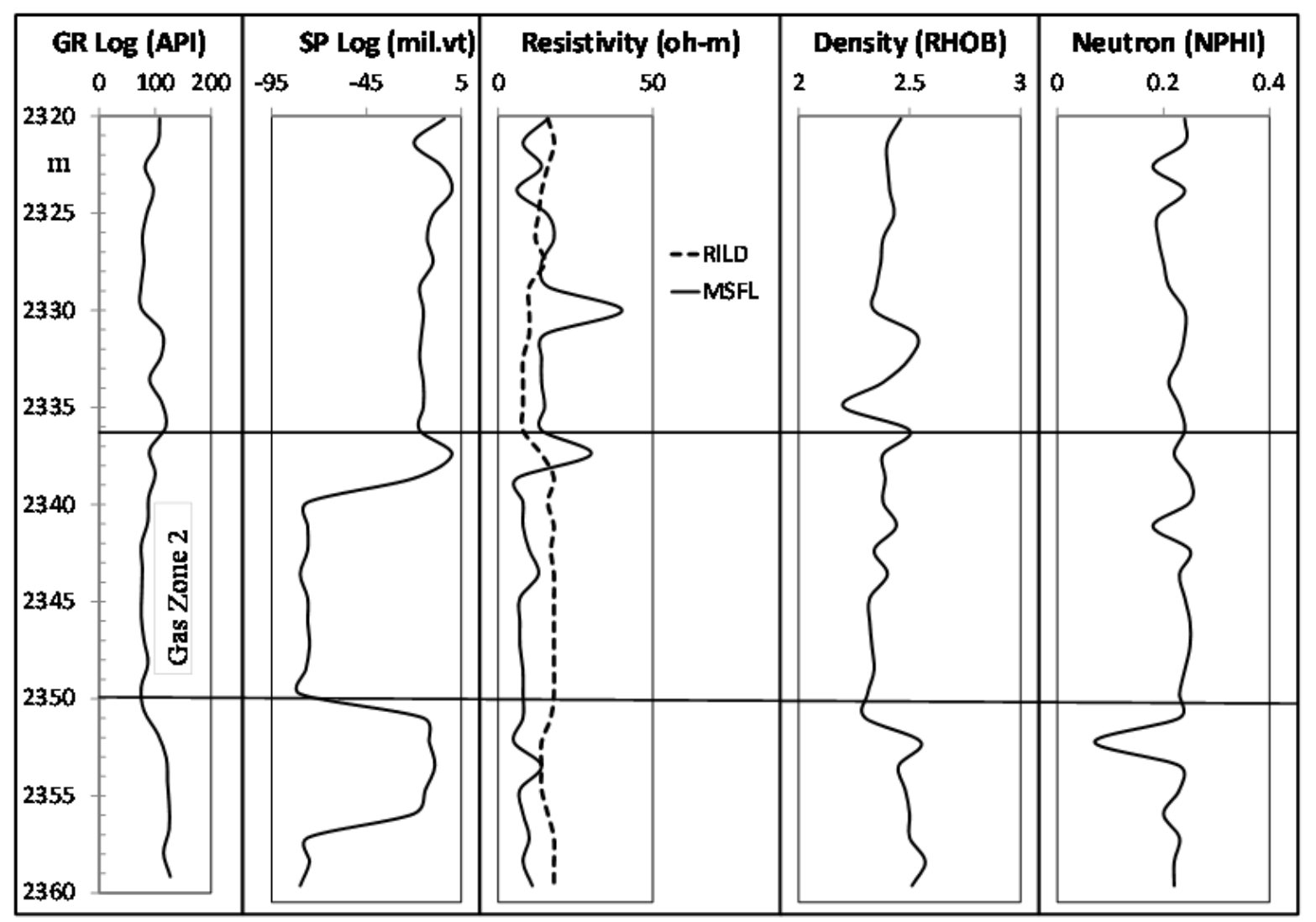

Fig. 2. Composite log responses of the hydrocarbon bearing Zone 2 (2337-2350 $\mathrm{m})$ identified in Mio-Pliocene sandstones of the well Rashidpur 4, the Bengal Basin, Bangladesh (Farhaduzzaman, 2013)

\section{Shale distribution}

Generally shale evaluation includes the determination of shale parameters as well as its volume and types. The determination of shale parameters often depends on the experience of $\log$ analyst since these parameters vary with different geological factors. Volume of shale in the hydrocarbon bearing zones of the reservoir sandstones of the studied well has been calculated using Schlumberger (1975) and Dresser Atlas (1979) formulas. The cutoff value of shale volume of shaly sandstone reservoir is about 20-30\% (Bassiouni, 1994). The average shale volume of the identified hydrocar- throughout the Mio-Pliocene reservoir intervals of the Bengal Basin, Bangladesh (Geochem Group, 1989).

\section{Porosity $(\varphi)$ distribution}

Porosity of rock is a fraction of void space compared to its total volume. The determination of porosity is a very important step for calculating fluid saturation in reservoir evaluation (Ruhovets, 1990). Neutron and density logs have been used to calculate porosity distribution for the current study. The porosity values of the individual zone 2 are graphically represented in Fig. 3. The cutoff porosity for sandstone reservoir is considered as 8\% (Asquith and Gibson, 1982). 


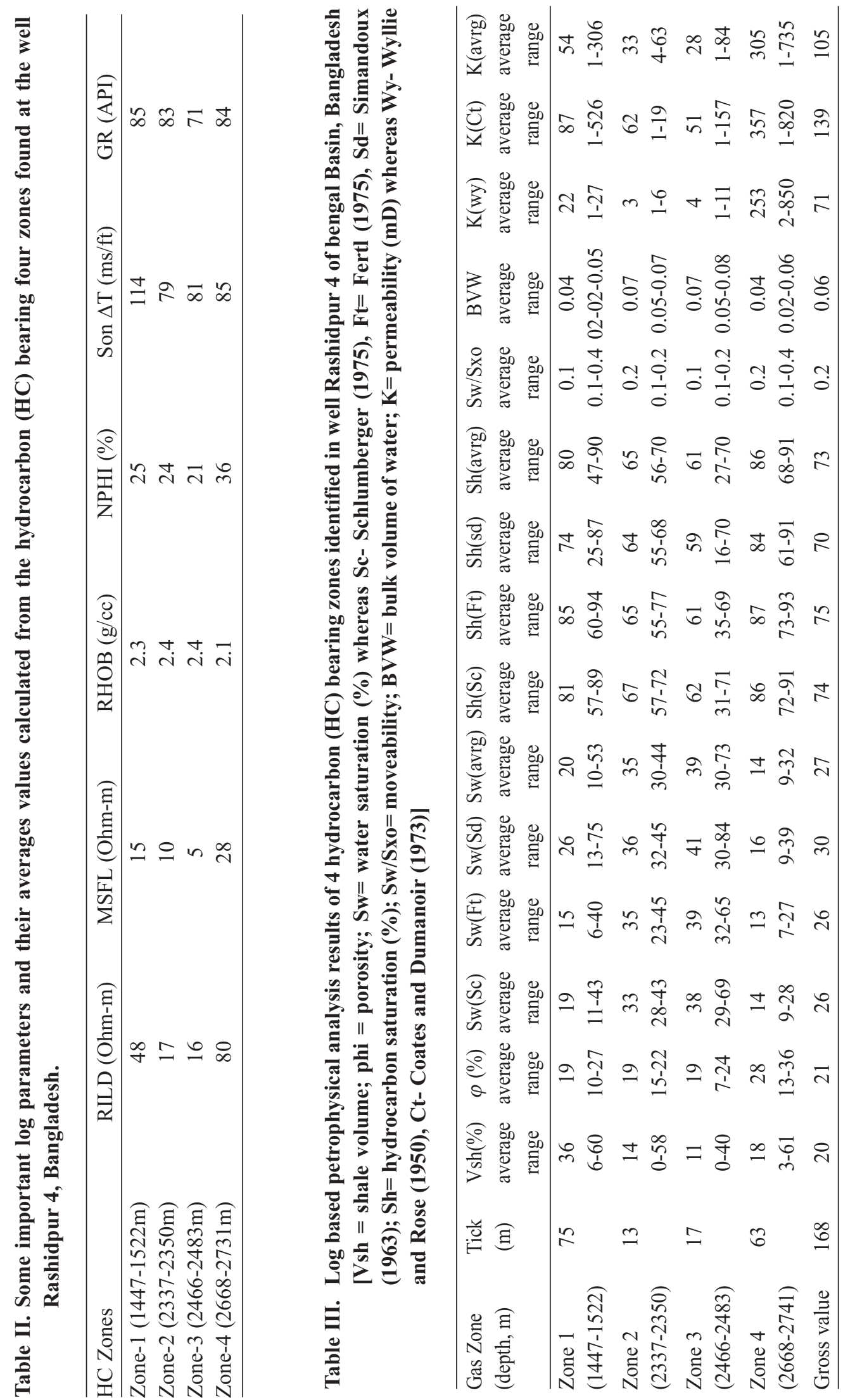


The estimated porosity of the hydrocarbon zones of the MioPliocene succession ranges from $7 \%$ to $36 \%$ having the thickness weighted average porosity of $22 \%$ (Table III). Based on porosity values, Bradley (1987) classified sandstone reservoirs as poor $(5-10 \%)$, fair (10-15\%), good (15$20 \%$ ), very good (20-25\%) and excellent (higher than $25 \%$ ) categories. Here, the studied sandstone reservoir is considered as very good category. The calculated porosity data is independent without having any control by any other means.

\section{Water saturation $\left(S_{w}\right)$ distribution}

Water saturation of the currently examined hydrocarbon bearing zones in the studied well has not used for Archie's (1942) formula. Because this formula is valid for clean sand lated average water saturation values of the four hydrocarbon bearing zones 1-4 in the well RP4 are 20\%, 35\%, 39\% and $14 \%$ respectively (Table III). Thickness weighted average water saturation of the examined reservoir sandstones is $20 \%$.

\section{Hydrocarbon saturation $\left(S_{h}\right)$ distribution}

Hydrocarbon saturation of a reservoir is determined by subtracting water saturation from the value of total saturation which is 1 (one). The permeable zone having more than $60 \%$ hydrocarbon saturation $\left(\mathrm{S}_{\mathrm{h}}\right)$ value is commonly treated as hydrocarbon bearing zone (Asquith and Gibson, 1982). Following all three commonly used formulas, $\mathrm{S}_{\mathrm{h}}$ values of all hydrocarbon bearing zones are greater than $60 \%$ (Fig. 3). Sometimes the presence of shale in the studied reservoir

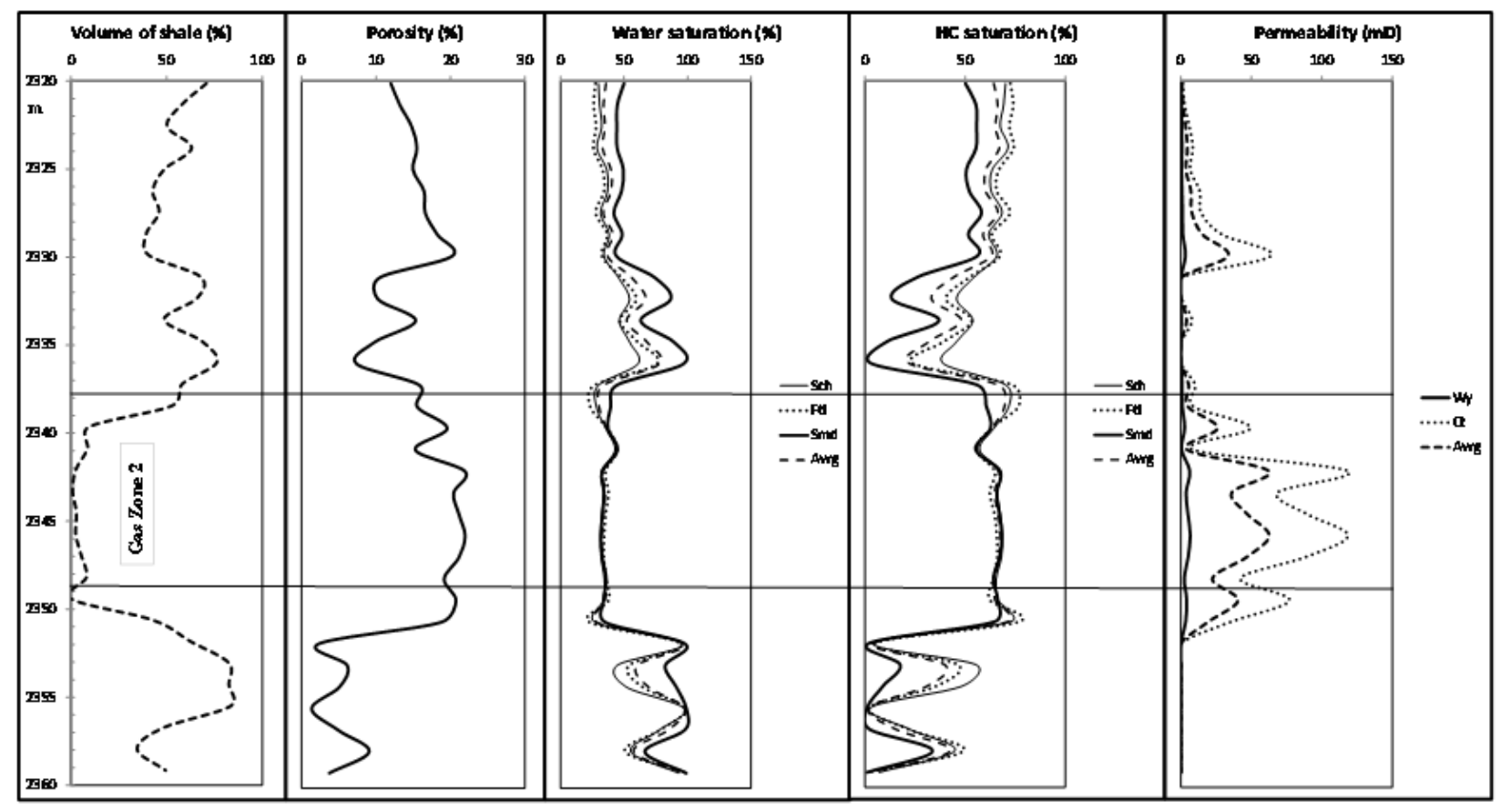

Fig. 3. Graphical presentation of the petrophysical parameters of the hydrocarbon bearing Zone 2 (2337-2350 m) identified in Mio-Pliocene sandstones of the well Rashidpur 4, the Bengal Basin, Bangladesh (Farhaduzzaman, 2013)

stone and the values are much affected by incursion of shale and porosity. Therefore, three most popular formula have been used which were proposed by Simandoux (1963), Fertl (1975) and Schlumberger (1975). For Zone 2, the calculated values of water saturation using these formulas are graphically represented in Fig. 3. Finally, the average value of the water saturation calculated from these three different formulas have been considered for further calculation. The calcu- sandstones decreases the content of $\mathrm{S}_{\mathrm{h}}$. In case of water saturation calculation, Schlumberger's formula (1975) has been found better suited among these three formulas (c.f., Islam et al., 2006; Islam, 2010). The calculated average values of hydrocarbon saturation of the zones 1-4 of the studied well RP4 are $80 \%, 65 \%, 61 \%$ and $86 \%$ respectively. $80 \%$ is the thickness weighted average hydrocarbon saturation of the studied sandstones. Based on hydrocarbon saturation, the zones can be ranked as Zone $4>$ Zone $1>$ Zone $2>$ Zone 3. 


\section{Permeability $(K)$ distribution}

Permeability is the property of a rock that relates transmission capability through the rock. The results of permeability measurement are shown in the Table III. The average permeability values of the gas zones 1-4 of the investigated reservoir sandstones are 54, 33, 28 and $305 \mathrm{mD}$ respectively.

Measured thickness weighted average permeability of the Mio-Pliocene reservoir is $144 \mathrm{mD}$. Considering its average permeability, Zone 4 is the most potential zone. All values calculated here indicate the identified hydrocarbon bearing zones are commonly good to very good reservoirs according to the generalized observation made by Asquith and Gibson (1982).

\section{Hydrocarbon moveability index $\left(S_{w} / S_{x o}\right)$}

Hydrocarbon moveability index is the ratio between water saturation of uninvaded zone $\left(S_{w}\right)$ to the water saturation of flushed zone $\left(S_{x o}\right)$. If the ratio of $S_{w}$ and $S_{x o}$ is $\geq 1$, then the hydrocarbon would not move toward the well bore. If this ratio is less than 0.7 (for sandstone), the hydrocarbon is considered as moveable (Schlumberger, 1972). From the calculated results (Table III), it can be inferred that the hydrocarbon of the selected zones in the studied well RP4 is moveable. Because all movability index values are less than 0.7 .

\section{Bulk volume of water (BVW)}

Bulk volume of water is the product of formation's water saturation and its porosity. It is important to know BVW whether the formation is at irreducible water saturation or not. When the value of BVW is constant or close to constant with some minor scattering, it indicates the homogenous formation having close to irreducible water saturation. If the BVW ranges from 0.035 to 0.07 , the grain size of the rock succession is fine to very fine grained sandstone (Fertl and Vercellino, 1978). The BVW values of the hydrocarbon bearing zones in the studied well have been calculated using Morris and Biggs (1967) formula. The calculated bulk volume of water is nearly constant with some minor scattering in the hydrocarbon bearing zones which indicate that the reservoir rock consists mainly of fine to medium grained sandstone.

Porosity and permeability are the two most important parameters which can be determined from well log analysis directly or indirectly (Asquith and Gibson, 1982). These characteristics of rock are affected by many ways during logging measurements. There are many variables and techniques to minimize the adverse down hole effects and drawbacks of some computation procedures. However, none of them is unique. For example, a, $\mathrm{m}$ and $\mathrm{n}$ are three parameters (constants) termed as tortuosity, cementation and saturation exponent. These parameters differ from rock to rock and basin to basin. In the Bengal Basin, there are no prescribed values of these parameters. In this study, the values of these parameters have been used in a generalized fashion and considered as $0.62,2.15$ and 2 respectively since these reservoir sands were unconsolidated (Asquith and Gibson, 1982). These values might also affect the overall calculations. Neutron, density and sonic log readings have been used to determine the porosity. Porosity measurements from density logs require matrix density. Most postulated matrix density for sandstone is $2.7 \mathrm{cc} / \mathrm{gm}$ (Schlumberger, 1972). Core derived density values from this study range from 2.1 to 2.6 $\mathrm{gm} / \mathrm{cc}$. The constant value of matrix density might also affect the porosity calculation from density log. The computation processes needs some correction due to shale effect on the log data because the studied reservoirs consist of more than $10 \%$ shale. If the effects of shale on the porosity measurement are not duly minimized, then the measurement might lead to deviation from the correct values. There is no known tool that can measure permeability without any error. Core derived permeability is often calculated based on empirical rather than measured studies. Well logs can predict relative indications of permeability, which are usually termed "permeability index" and are qualitative rather than quantitative. The quality of the index hinges on the quality of the data (Brock, 1986). The hardest parameter to pin-point is that of irreducible water saturation $\left(\mathrm{S}_{\text {wirr }}\right)$.

Log derived permeability formulas are only valid for estimating permeability in formation with irreducible water saturation (Schlumberger, 1977). The product of water saturation $\left(\mathrm{S}_{\mathrm{W}}\right)$ and porosity $(\varnothing)$ is known as bulk volume of water (BVW). If values for BVW across the reservoir interval are constant or very close to constant, then the hydrocarbon production from the reservoir should be water free. Hence, the saturated water in the uninvaded zone will not move due to capillary pressure existing between the sediment grains (Morris and Biggs, 1967). Nevertheless, it is always difficult to find a reservoir at irreducible water saturation state due to heterogeneities in the reservoir properties. The present study also suffers from this difficulty. In shaly sand calculation, the shale parameters within the reservoir translated from the 
neighboring shale zone which may not be the same in all cases.

In present study, thin section porosity is also measured for the sandstone samples using Leica DMLP optical microscope. The measured porosity ranges from $17 \%$ to $23 \%$ having the average value of $19 \%$ as observed in the thin sections. The log derived average porosity value is $7-36 \%$ (average $22 \%$ ). There is a slight increase of porosity values in case of $\log$ analysis. Only five selected sandstone samples of
RP4 are chosen for petrographic (thin section) analysis. Here comparatively shale free sandy samples are considered for measurement. This is obvious that relatively clean sandstone provides high permeability and comparatively high porosity. It is because of the fact that due to larger pore radius core samples exhibit high permeability and porosity. Because of shale effect, the log measurements exhibit significant increase in porosity and a decrease in permeability. Four gas zones from the well RP4 consist of 168 m thick gas sands.

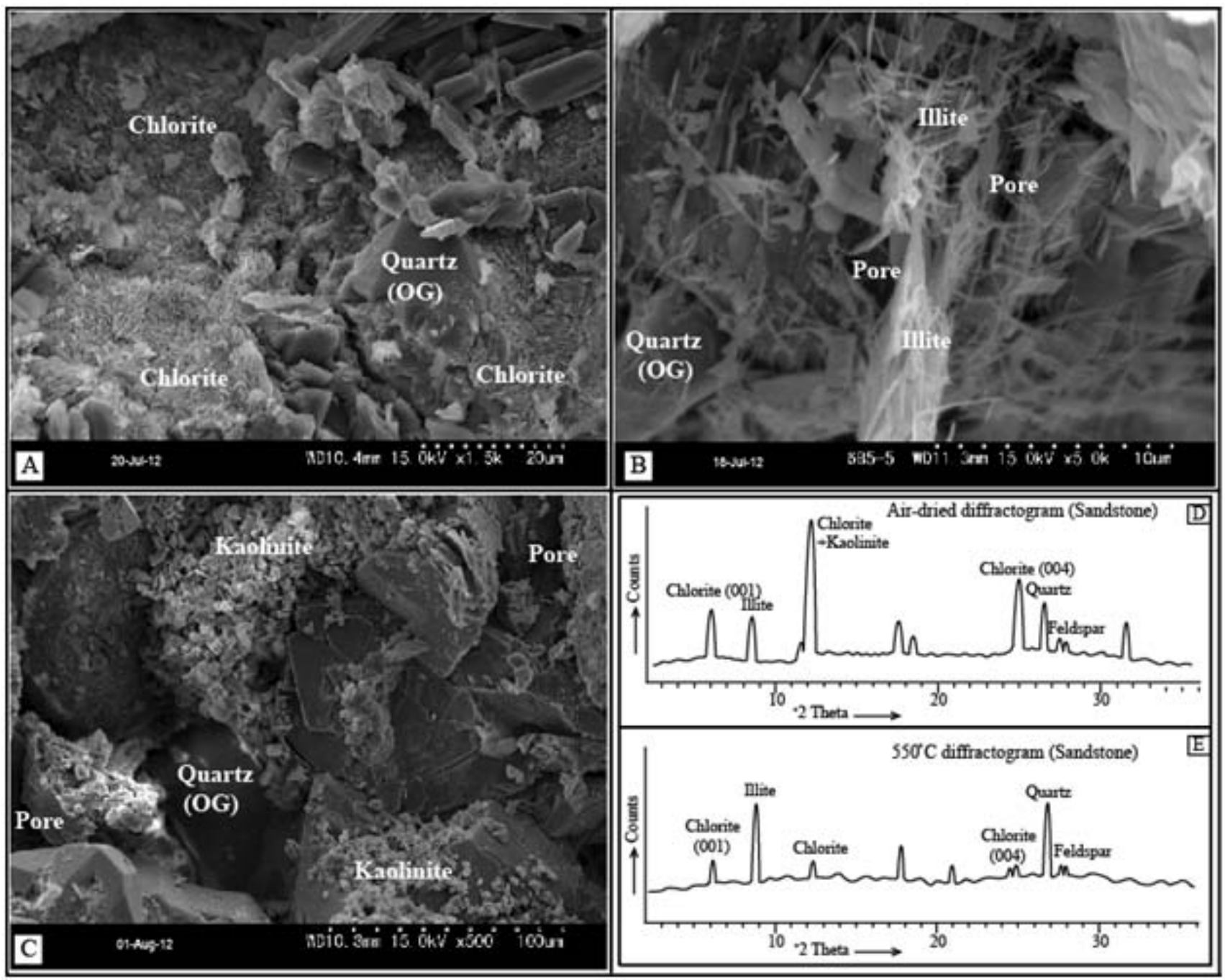

Fig. 4. The clay minerals observed within the studied sandstones of Rashidpur 4 using scanning electron microscopic and XRD. (A) Clusters of pore-filling euhedral and pseudohexagonal chlorite crystals, depth $2683 \mathrm{~m}$. (B) The filamentous illite coating the detrital grain surfaces associated with quartz overgrowth, depth $2757 \mathrm{~m}$. (C) Kaolinite books, face-to-face stacks of pseudohexagonal plates, partly occluded the pore throats, depth 2670 m. (D) Non-treated air-dried $x$-ray diffractogram of sandstone samples. Here chlorite, illite and kaolinite clay minerals are identified. (E) $550{ }^{\circ} \mathrm{C}$ heated $\mathrm{x}$-ray diffractogram of sandstone sample and hence the kaolinite peak is disappeared remained a small peak for chlorite (e.g., Moore and Reynolds, 1979; Farhaduzzaman, 2013) 
So, huge data points even from thinly laminated shaly horizon are accompanied by comparatively less shaly sandy horizon increase the log porosity and decrease the log permeability. The heterogeneity of the studied reservoirs might be responsible for down grading the log permeability values.

There are many examples from petroleum basins around the world that the permeability of petroleum reservoir rocks may range from 0.1 to 1000 or more millidarcies (Islam, 2010). The quality of a reservoir as determined by permeability (in $\mathrm{mD})$ may be ranked as poor if $\mathrm{K}<1 \mathrm{mD}$, fair if $1 \mathrm{mD}<\mathrm{K}<10 \mathrm{mD}$, moderate if $10 \mathrm{mD}<\mathrm{K}<50 \mathrm{mD}$, good if $50 \mathrm{mD}<\mathrm{K}<250 \mathrm{mD}$ and very good if $\mathrm{K}>250 \mathrm{mD}$ (Tiab and Donaldson, 1996). The average permeability measured for the gas zones ranges from 28 to $306 \mathrm{mD}$. In this regard, permeability values of all reservoir intervals of the well Rashidpur 4 indicate good to very good quality reservoirs (Table III). Porosity, hydrocarbon saturation and movability index values of the selected hydrocarbon zones also advocate in favor of good to very good reservoir condition in the Bengal Basin. This interpretation is also supported from different reports (Imam 2013; Islam 2009 and 2010 Rahman and McCann, 2012). The identified zone $4(2668-2731 \mathrm{~m})$ is the most potential hydrocarbon bearing zone based on its porosity. This is also supported by other parameters like hydrocarbon saturation and permeability. The studied clays within the reservoir sandstone samples are mixed types (i.e., chlorite, illite and kaolinite) throughout the Mio-Pliocene Surma Group. This is consistent with the interpretation made with the help of XRD and microscopic study (Fig. 4). It is also reported by others (Imam and Shaw, 1987; Islam 2009 and 2010; Rahman and McCann, 2012). Anomaly in log based measurements may be because of the inherent problems of different formulas, e.g., selection of saturation and permeability formulas and constraints related to values of different constants.

\section{Conclusion}

Among twenty permeable zones identified in the well RP4, four potential gas zones are indicated. Their gross cumulative thickness is $168 \mathrm{~m}$. The study measures the log derived petrophysical parameters including shale volume, porosity, water saturation, hydrocarbon saturation, permeability, moveability index and bulk volume of water. The values are (average) 20\%, 22\%, 20\%, 80\%, 144mD, 0.2, 0.06 respectively. Hydrocarbons of these zones are moveable since $\mathrm{S}_{w} / \mathrm{S}_{x o}$ is found less than 0.7 . Schlumberger equation is found more suitable for water saturation calculation comparing with Fertl and Simandoux equations. The log derived porosity slightly exceeds thin section porosity. Bulk volume of water of the hydrocarbon zones indicates fine to medium grained sandstone which is also supported by the physical examination of the samples. Petrographic evidences and XRD results confirms the dominance of mixed type of clays including chlorite, illite and kaolinite in the examined sandstones. The study reveals that all of the four gas zones possess good to very good reservoirs in the well RP4. This good to very good quality reservoir quality is also supported by the interpretation based on petrography. Nonetheless, zone 4 is considered the best potential for hydrocarbon production of the well Rashidpur 4.

\section{Acknowledgements}

The authors are grateful to chairman of Petrobangla for supplying data/samples. Sylhet Gas Fields Ltd, Petrobangla deserves appreciation for official support (M.F.) to carry out this research. Prof. Khalil R. Chowdhury and his colleagues at Jahangirnagar University have encouraged much for the present research $(\mathrm{PhD})$. The authors also acknowledge the financial support grants PV100-2011A and RG145-11AFR and Bright Sparks Fellowship BSP-APP-1080-2012 of UM.

\section{References}

Alam M, Alam MM, Curray JR, Chowdhury MLR and Gani MR (2003), An overview of the sedimentary geology of the Bengal Basin in relation to the regional tectonic framework and basin-fill history, Sed. Geol. 155(3-4): 179-208.

Asquith GB and Gibson RC (1982), Basic well log analysis for geologist, The AAPG, Houston 1982, pp 216.

Atlas D (1979), Log interpretation chart, Dresser industries Inc., Houston pp107.

Banerji RK (1984), Post-Eocene biofacies, palaeoenvironments and palaeogeography of the Bengal Basin, India, Palaeog, Palaeocli. Palaeoeco. 45(1): 49-73.

Bassiouni Z (1994), Theory, measurement and interpretation of well logs. Soc. Petrol. Engr., USA, pp 384.

Bateman RM and Konen C E (1977), The log analyst and the programmable pocket calculator. The Log Analyst 18(5): 3-11. 
Bradley H (1987), Petroleum engineering handbookProperties of reservoir rocks. Soc. Petrol. Engr., USA, pp 418.

Brock J (1986), Applied open-hole log analysis. (Gulf Publishing Company, USA), pp 284.

Coates G and Dumanoir JL (1973), A new approach to improve log-derived permeability. In: Proc. of the 14th Ann. Logging Symposium. Soc. Pro. Well Log Anal., USA, pp 103-201.

Farhaduzzaman M, Abdullah WH, Islam MA and Pearson MJ (2012a), Source rock potential of organic-rich shales in the Tertiary Bhuban and Boka Bil Formations, Bengal Basin, Bangladesh. J. Petrol. Geol. 35(4): 357-376.

Farhaduzzaman M, Wan Hasiah A and Islam MA (2012b), Depositional environment and hydrocarbon source potential of the Permian Gondwana coals from the Barapukuria Basin, northwest Bangladesh, Int. J. Coal Geol. 90-91:162-179.

Farhaduzzaman M (2013), Characterization of selected petroleum source rocks and reservoir rocks of Bengal Basin (Bangladesh) based on geochemical, petrographical and petrophysical methods, $\mathrm{PhD}$ Thesis submitted to the Department of Geology, University of Malaya, Kuala Lumpur, p 308.

Farhaduzzaman M, Abdullah WH and Islam MA (2013a), Petrographic characteristics and palaeoenvironment of the Permian coal resources of the Barapukuria and Dighipara Basins, Bangladesh, J. Asian Earth Scs. 64: 272-287.

Farhaduzzaman M, Abdullah WH, Islam MA and Pearson M J (2013b), Organic facies variations and hydrocarbon generation potential of Permian Gondwana Group coals and associated sediments, Barapukuria and Dighipara Basins, NW Bangladesh, J. Petrol. Geol. 36(2): 117-138.

Farhaduzzaman M, Wan Hasiah A and Islam MA (2014), Hydrocarbon source potential and depositional environment of the Surma Group shales of Bengal basin, Bangladesh, J. Geol. Soc. India 83(4):433-446.

Fertl WH (1975), Shaly-sand analysis in development wells, In: Proc. of 16th Ann. Logging Symposium. Soc. Pro.
Well Log Anal., USA, pp 87-102.

Fertl WH and Vercellino WC (1978), Predict water cut from well logs. In: Practical log analysis-4. Oil and Gas Jour. 4: 32-45.

Geochem Group (1989), Geological report on the well Rashidpur 4. A report prepared for Petrobangla unpublished, Geochem, Dhaka, pp 218.

Hossain MMA (2012), Pump oil, outshine debate, Energy and Power 9(24): 9-12.

Imam MB and Shaw HF (1987), Diagenetic controls on the reservoir properties of gas bearing Neogene Surma Group sandstones in the Bengal Basin, Bangladesh, Mar. Petrol. Geol. 4(2): 103-111.

Imam MB (2013), Energy resources of Bangladesh. University Grants Commission, Dhaka, pp 280.

Islam MA (2009), Diagenesis and reservoir quality of Bhuban sandstones (Neogene), Titas Gas Field, Bengal Basin, Bangladesh, J. Asian Earth Scs. 35(1): 89-100.

Islam, MA (2010), Petrophysical evaluation of subsurface reservoir sandstones of Bengal Basin, Bangladesh, $J$. Geol. Soc. India 76(6): 621-631.

Islam MA, Sultan-Ul-Islam M, Hasan Latif M, Mondal D and Abdullah-Al-Mahbub (2006), Petrophysical analysis of shaly sand gas reservoir of Titas Gas Field using well logs, Bangladesh J. Geol. 25: 106-124.

Jamaluddin M, Nasrin N, Rahman M, Anwara H and Bygdevold J (2001), Bangladesh petroleum potential and resource assessment, Report for HCU and NPD, Dhaka, pp 200.

Moore DM and Reynolds RCJ (1979), X-ray diffraction and the identification and analysis of clay minerals, Oxford University Press, USA, pp 400.

Morris RL and Biggs WP (1967), Using log-derived values of water saturation and porosity. In: Proc. of 8th Ann. Logging Symposium, Soc. Prof. Well Log Anal., USA, pp 27-36.

Petrobangla (2015), http://www.petrobangla.org.bd, Accessed website on 04 Dec 2015. 
Rahman MJJ and McCann T (2012), Diagenetic history of the Surma Group sandstones (Miocene) in the Surma Basin, Bangladesh, J. Asian Earth Scs. 45: 65-78.

Ruhovets N (1990), A log analysis technique for evaluating laminated reservoirs in the gulf coast area, The Log Analyst 31: 294-303.

Sakurai S, Grimaldo-Suarez FM, Aguilera-Gomez LE and Rodriguez-Larios JA (2002), Estimate of lithology and net gas sand from wireline logs: Veracruz and Macuspana Basins, Mexico. Gulf Coast Asso. Geol. Soc. Transac. 52: 871-881.

Sclumberger (1972), Log interpretation manual/principles, Schlumberger Well Services Inc., Houston, pp 238.

Schlumberger (1975), A guide to well site interpretation of the gulf coast, Schlumberger Well Services Inc., Houston, pp 301.

Schlumberger (1977), Log interpretation charts, Schlumberger Well Services Inc., Houston, pp 402.

Shamsuddin AKM, Huq MM, Faruque MA, Chudhury Z and Rafdal J (2004), Bangladesh gas reserve estimation 2003, Report for HCU and NPD, Dhaka, pp 254.
Simandoux P (1963), Measures dielectriques en milieu poreux, application a measure des saturations en eau: Etude du comportement des massifs argleux. Revue de I'institut Francais du Petrole. Supplementary Issue.

Tiab D and Donaldson EC (1996), Theory and practice of measuring reservoir rock and fluid transport properties, Gulf Publishing Co., Houston, pp 709.

Uddin A and Lundberg N (2004), Miocene sedimentation and subsidence during continent-continent collision, Bengal Basin, Bangladesh, Sed. Geol. 164(1-2): 131146.

Waxman WH and Smits IJM (1968), Electrical conductivities in oil-bearing sands, Soc. Petrol. Engrs. Jour. 8: 107-122.

Wyllie MRJ and Rose WD (1950), Some theoretical considerations related to the quantitative evaluations of the physical characteristics of reservoir rock from electric log data, J. Petrol. Tech. 189: 105-110.

Received: 22 May 2014; Revised: 06 December 2015; Accepted: 31 January 2016. 